\title{
Implementation of Active Learning Learning Model Using the Google Classroom Application in Comparative Literature Courses
}

\section{Amrizal a1, Amril Canrhas ${ }^{\text {b2 }}$, Fina Hiasa ${ }^{c 3^{*}}$}

Prodi Pendidikan Bahasa Indonesia, Fakultas Keguruan dan Ilmu Pendidikan, Universitas Bengkulu ${ }^{\mathrm{a}, \mathrm{b}, \mathrm{c}}$

amrizal@unib.ac.id'; amrilcanrhas@,unib.ac.id ${ }^{2}$; finahiasa@,unib.ac.id ${ }^{3}$

*author correspondence

\begin{tabular}{ll}
\hline Informasi artikel & \\
\hline Sejarah artikel: & \\
Diterima: & 2 Juni 202I \\
Revisi: & I4 September 202I \\
Dipublikasikan: & 30 Oktober 202I \\
\hline
\end{tabular}

ABSTRAK

Kata kunci:

Penelitian ini bertujuan untuk mengetahui bagaimana implementasi model pembelajaran Active Learning berbantuan aplikasi Google Classroom pada mata kuliah Sastra Bandingan dapat meningkatkan kualitas pembelajaran mahasiswa semester lima Prodi Pendidikan Bahasa Indonesia FKIP Universitas Bengkulu.

Active Learning,

Google Classroom,

Sastra Bandingan Metode Research and Development ( $R \& D$ ) adalah metode yang digunakan dalam penelitian ini dengan tujuan untuk menguji apakah implementasi model pembelajaran Active Learning menggunakan aplikasi Google Classroom dapat meningkatan kualitas pembelajaran. Implementasi yang ingin dibuktikan tersebut terlihat dari beberapa tahapan yang dilakukan pada penelitian ini yaitu studi pendahuluan, tahapan pengembangan, uji coba produk, dan evaluasi produk. Kegiatan ujicoba produk berupa tes dalam bentuk esai dan pilihan ganda menggunakan Active Learning berbantuan aplikasi Google Classroom menunjukkan capaian hasil belajar yang baik dimana rata-rata skor yang diperoleh mahasiswa peserta latihan pada sastra bandingan yaitu sebesar 85,5 dari skor ratarata maksimal 100 poin. Hal ini menunjukkan penerapan model pembelajaran aktif berbantuan Google Classroom pada mata kuliah Sastra Bandingan membuat proses pembelajaran menjadi efektif dan menyenangkan untuk mahasiswa.

Key word:

Active Learning,

Google Classroom,

Comparative Literature

\begin{abstract}
This study aims to determine how the implementation of the Active Learning learning model assisted by the Google Classroom application in the Comparative Literature course can improve the learning quality of the fifth semester students of the Indonesian Language Education Study Program, FKIP, Bengkulu University. The Research and Development (R\&D) method is a method used in this study with the aim of testing whether the implementation of the Active Learning learning model using the Google Classroom application can improve the quality of learning. The implementation that you want to prove can be seen from several stages carried out in this study, namely preliminary studies, development stages, product testing, and product evaluation. Product testing activities in the form of tests in the form of essays and multiple choice using Active Learning assisted by the Google Classroom application showed good learning outcomes where the average score obtained by trainee students in comparative literature was 85.5 from a maximum average score of 100 points. This shows that the application of the active learning model assisted by Google Clasroom in the Comparative Literature course makes the learning process effective and enjoyable for students.
\end{abstract}

Copyright (C) 2018 Universitas Ahmad Dahlan. All Right Reserved

\section{Introduction}

Comparative literature is the study of literature that allows learners to understand more thoroughly the content of a literary work. In its development, comparative literary studies have compared works not only between regional literatures but to regional literary works and international literary works (Mayasari, 20II: 2I0). In Western Europe and America, comparative literary theory has become the leading location for literary works (Suwardi, 2010: 13). Suwardi (2010) conveys theoretical considerations in comparative literature studies, namely: a) It is necessary to combine literary theory and other theories to break the boredom of comparative literature, b) The theory of study which adopts both positivistic and naturalistic views, should be arranged systematically, logically, and meaningful, c) The main theories that are able to open the aesthetic and pragmatic insights of literature are appropriate to be used, d) Comparative literature should still use theories that are able to maintain the identity of a literary work as a mirror of time and space. 
Comparative literature as a complex and student-studied study requires a lecturer who is able to provide guidance to students in the form of teaching. Students of the Bengkulu University FKIP Indonesian Language Education Study Program are students who are prepared to become professional teachers in the Indonesian language field. Therefore, teaching comparative literature cannot be carried out normally without ignoring the boredom of students that can arise during the learning and teaching process. Innovation should be applied to prepare for all situations.

The President issued Decree number 12 of 2020 on April I3, 2020 concerning the Designation of NonNatural Disasters of the Corona Virus Disease 2019 (Covid-19) as a national disaster. As a result, the social life of the people of the Republic of Indonesia has changed even to the learning activities at universities. The implementation of learning and teaching will be different than usual. Bengkulu University is a university that enforces learning from home or work from home. Learning from home has changed the way lecturers deliver lecture material from face-to-face to online lectures.

Online lectures allow lecturers and students not to meet face to face. However, students' interest in learning still decreases because there is no direct supervision from the lecturer so that students can open other applications when online learning is carried out, which reduces their learning achievement (Miskahuddin, 2017: 294). One of the appropriate learning models so that students feel considered and don't bore them in online learning is the active learning model. The active learning model is a learning model with students as parties who really play an active role in the learning and teaching process. This learning model emphasizes the process not the result (Hosnan, 20I4: 208). When lecturers deliver material, students are tested to draw their previous understanding so that students will think critically and analyze.

In the condition of online lectures, the lecturer will ask students in comparative literature learning to read the two types of literature contained in the virtual class then with a pleasant language style, the lecturer will direct students to understand the difference between the two types of literature which is referred to as the initial stage in comparative literature learning. With this online system, we need an application that is friendly and easy to use by educators. One of them is the Google Classroom application. This application is one of the software products owned by Google. Google presents this application with the aim that education can be accessed by anyone easily and the quality of learning is maintained. This is very suitable for learning in the pandemic era where Google Classroom is present as an alternative application that can be used in learning that has a simple and user-friendly style.

Some of the advantages of the Google Classroom application are as follows; I) a simple registration process, 2) educators can directly edit or correct assignments in real time so that learning is more comprehensive, 3) data is stored regularly which can be accessed anytime and anywhere without worrying about losing files. Compared to similar applications, it can be concluded that Google Classroom has a more effective and efficient concept for users, although the weakness of this application is that it can only be accessed by users who have a Google account. But this weakness is not a crucial problem because in today's era the average person has a Google account. Below is an example of how Google Classroom looks in learning activities.

From the search results of previous research, it is known that research on the application of learning models using the Google Classroom application has been carried out. For example, a research conducted by Nafiah and Hartatik (2020) in the Journal of Education and Human Development Journal with the title Application of Online-Based Learning Management Using the Google Classroom Application to Improve Student Ability in Making Learning Devices. The purpose of this study was to determine the application of online-based learning management using the google classroom application to improve students' ability to make learning tools in learning planning courses in the SI PGSD FKIP UNUSA Study Program. The results of this study are that in the first cycle of the first meeting the average value of the preparation of elementary school learning tools (Prota, Prosem / Promes, Syllabus, RPP) is around 45, while at the second meeting the average value of learning devices is around 68.25. In the second cycle at the first meeting the average value for the preparation of learning devices was around 73.5 , while at the second meeting the average value of students in the preparation of elementary learning tools was 96.75 .

Learning through the Google Classroom application is very supportive of current conditions. This is because universities are urged to reduce the impact of the spread of Covid-19. So, the only step for lecturers to interact with their students is through online learning. This application is designed for virtual learning. Research on Google Classroom has also been conducted by Prawoto (2019). But the research does not focus on online learning alone but also focuses on face-to-face learning. In addition, the research mentioned also does not focus on the topic of comparative literature learning. Research on increasing the effectiveness of comparative literature learning in virtual classrooms is still limited. In fact, the current condition of Covid-I9 requires lecturers to be 
able to innovate with teaching procedures. If the results of the research show positive results with the students of the Indonesian Language Education Study Program, FKIP, Bengkulu University, their interest in learning is increasing, it can be a reference and alternative for solving the problems of student interest in learning in other subjects in the current Covid-19 situation.

\section{Methods}

The Research and Development (R\&D) method is the method used in this study. This research is guided by the following stages, namely; a) preliminary studies, b) development stages, c) product trials, d) product evaluation. The research subjects were researchers acting as lecturers of Comparative Literature courses and students taking Comparative Literature courses. The population of this study were all students of the Indonesian Language Education Study Program, FKIP UNIB T.A. 2020/202I. While the sample in this study were fifth semester students of class A Indonesian Language Education Study Program, FKIP UNIB who were taking Comparative Literature courses.

The research instrument is a tool used to collect research data. The instruments used are objective questions and essays that can be accessed via google classroom. This test is used to measure the level of mastery of the material by students. In addition, there is also a questionnaire containing student responses and suggestions for the learning that researchers provide after the test is carried out.Data analysis techniques used in this study were descriptive statistics, calculating frequency, and percentages presented with tables and graphs. Categories in the data will be adjusted according to existing percentages. Following is the formula that will be used in data processing.

$$
\begin{array}{ll}
\mathrm{X}=\frac{€ \mathrm{X}}{€ \mathrm{Xmaks}} & \mathrm{x} 100 \% \\
\text { Keterangan } & =\text { the value sought in percent } \\
\mathrm{X} & =\text { Total student grades } \\
€ X & =\text { Total score } \\
€ X \text { maks } &
\end{array}
$$

Table I. Kategori Penilaian (Modifikasi Nurgiyantoro, I988:363)

\begin{tabular}{ccc}
\hline No & Percentage & Category \\
\hline I & $80 \%-100 \%$ & Very good \\
\hline 2 & $70 \%-79 \%$ & Good \\
\hline 3 & $60 \%-69 \%$ & Fair \\
\hline 4 & $45 \%-59 \%$ & Bad \\
\hline 5 & $0 \%-44 \%$ & Very bad \\
\hline
\end{tabular}

\section{Results and Discussion}

The research was carried out on fifth semester students of class A of the Indonesian Language Education Study Program, FKIP, Bengkulu University who took comparative literature courses. After the implementation of the learning was carried out, the results showed that the Implementation of the Active Learning Model Using the Google Classroom Application in the Comparative Literature Course in the Indonesian Language Education Study Program, FKIP, Bengkulu University was effective in improving learning outcomes. The following is a description of the stages of the research that has been carried out.

\section{a. Preliminary Studies}

At this stage the researcher conducts a literature study to gather various information about active learning models, Google Classroom, and comparative literature. This study focuses on comparative literature learning activities with an active learning model using the Google Classroom application during the Covid-I9 pandemic. The researcher then prepared 20 questions which were divided into 4 quizzes. The quiz itself consists of 5 
questions. Each question in one quiz contains 20 points, if in one quiz a student answers correctly, the maximum score is 100 points.

\section{b. Development Stages}

After compiling 20 items to be used in 4 comparative literature quizzes assisted by Google Classroom, the researchers began arranging each question so that it could be accessed by students. However, before distributing materials, questions, and directions for each lesson, before that the researchers prepared the Google Clasroom virtual class first and prepared a WhatssApp group as well so they could coordinate with students. If you already have a Google Classroom, the next step is to determine the class name, prepare the material, and share the class link with students. In making questions, the researcher can determine whether the question is multiple choice or an essay, depending on the researcher's needs to prove the success rate of this learning. Previously, both researchers and students were required to install the google classroom application. There are three main classes of this application, namely the forum section, the class assignment section, and the members section. Once ready, the researcher can start teaching virtually by planning an agreement with previous students regarding class hours. Then add material / assignments / questions to the class work section. In this section, after the researcher has finished implementing learning with an active learning model, the researcher will give a quiz at the end of the lesson. Each quiz consists of five items in an essay where the researcher can show the rules for each quiz so that the instructions will be clear. The following is the google classroom link that the researcher has prepared https://classroom.google.com/c/MTUINzY2Mzk4NTQx?cjc=ciiuetz

\section{c. Product Trials}

After the product was developed with all the provisions that had been conveyed through the Google Clasroom training information, the researchers conducted a product test on 4I class A students of class A Indonesian Language Education Study Program FKIP Bengkulu University in comparative literature courses. Instruments that have been arranged for practice are considered efficient because students without the guidance of researchers can use and answer every existing question. Students can also work according to the time they can even though the quiz has a deadline for answering questions. This is because the active learning model with the critical incident method has made students happy in the implementation of learning so that they actively ask questions about the existing material.

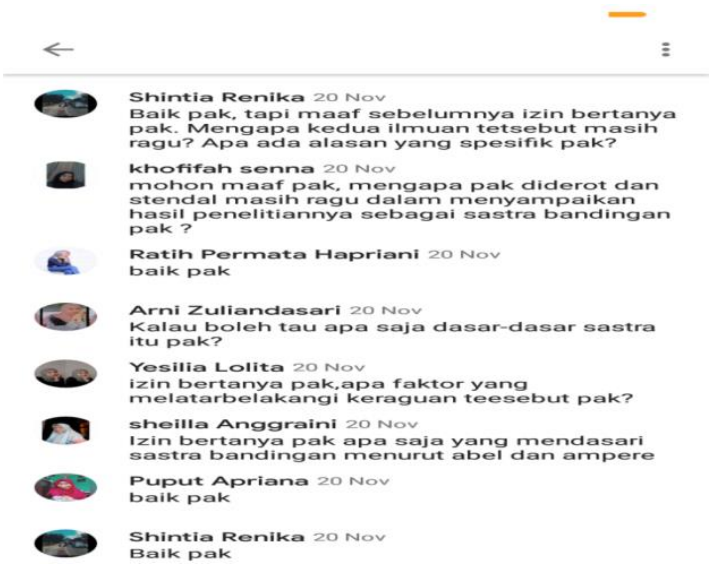

Figure I. Documentation of Assisted Comparative Literature Learning Activities

Google Classroom This activity is represented by student learning outcomes. Researchers prepare quizzes on google classroom to find out the extent to which students understand the material. The following is the google classroom
link
that the researcher
has
prepared

https://classroom.google.com/c/MTUINzY2Mzk4NTQx?cjc=ciiuetz.

In training activities in the form of Google Classroom assisted quizzes, students were enthusiastic about answering questions. When correcting, the researcher does not bother because a summary facility has been 
presented so that the answers and students who have answered the questions can be known. The following are the results of the comparative literary quiz obtained.

\begin{tabular}{lcccc}
\hline No & Quiz & \multicolumn{3}{c}{ RESULTS } \\
\cline { 3 - 5 } & & $\begin{array}{c}\text { The highest } \\
\text { score }\end{array}$ & $\begin{array}{c}\text { Lowest } \\
\text { Value }\end{array}$ & $\begin{array}{c}\text { Number of Missed } \\
\text { Questions }\end{array}$ \\
\hline I & Quiz I & 82 & 62 & $0 \%$ \\
\hline $\mathbf{2}$ & Quiz 2 & 85 & 67 & $0 \%$ \\
\hline $\mathbf{3}$ & Quiz 3 & 80 & 60 & $0 \%$ \\
\hline $\mathbf{4}$ & Quiz 4 & 95 & 76 & $0 \%$ \\
\hline $\mathbf{5}$ & Average & 85,5 & 66,2 & $0 \%$ \\
\hline
\end{tabular}

In the table above, it can be seen that the average score obtained by students participating in the exercise in comparative literature is 85.5 from the maximum average score of 100 points. While the lowest average score for students was in quiz 3 with a score of 60 out of 100 points, while the highest score for students in comparative literature activities on quiz 4 was 95 points. This shows that the implementation of the Google Classroom assisted active learning model has resulted in a good learning process for students. Meanwhile, in each essay question which is a post test question, students answer based on their respective understanding. Researchers will get information on which students have submitted their training results.

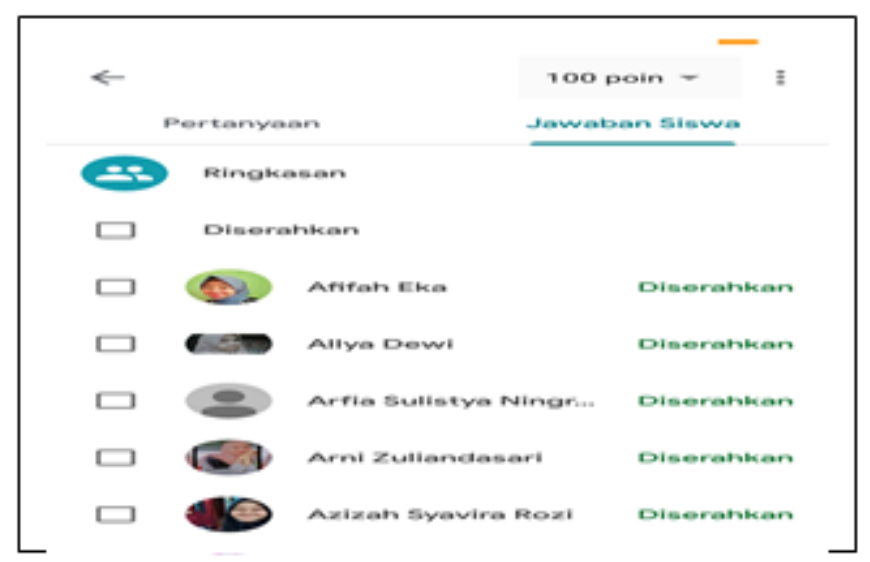

Figure 2. Students who have submitted their exercises to Google Classroom Assisted Comparative Literature

The results of the post test in the form of essay questions that were done in Google Classroom were $\mathrm{I} 2$ people (31\%) with A, I9 (50\%) in B, 8 C's (19\%) and D with $0 \%$. From these results it can be concluded that not only has there been an increase in learning outcomes in the previous quizzes / exercises but the results of the post-test also show that the learning outcomes in general are good, which means that the use of active learning models with google classroom assisted group discussions has been successfully implemented.

\section{d. Product Evaluation}

The application of active learning begins with the lecturer by directing students to understand a topic of discussion from various sources. Then, students are asked to ask questions about the material that they do not understand. Then, the lecturer gave a guessing game to the material to be discussed. Lecturers facilitate students' answers. After carrying out product trials, the researcher evaluates the products that the researcher has developed by asking for feedback and suggestions from students about the implementation of Google Classroom learning and training activities so far. 
The evaluation is carried out in the form of a questionnaire which is divided into 3 , namely: a) Questionnaire I, the effectiveness of using Google Classroom in Comparative Literature courses, b) Questionnaire 2 , the effectiveness of learning using Google Classroom when compared with writing tools (manual), and c) Questionnaire 3, student learning motivation by learning through Google Classroom. The questionnaire contains a statement with each choice consisting of I. Strongly agree 2. Agree 3. Disagree 4. Sufficiently agree 5. Less agree. After the questionnaire was filled in by students, the following results were obtained:

Pembelajaran melalui Google Classroom efektif.

37 tanggapan

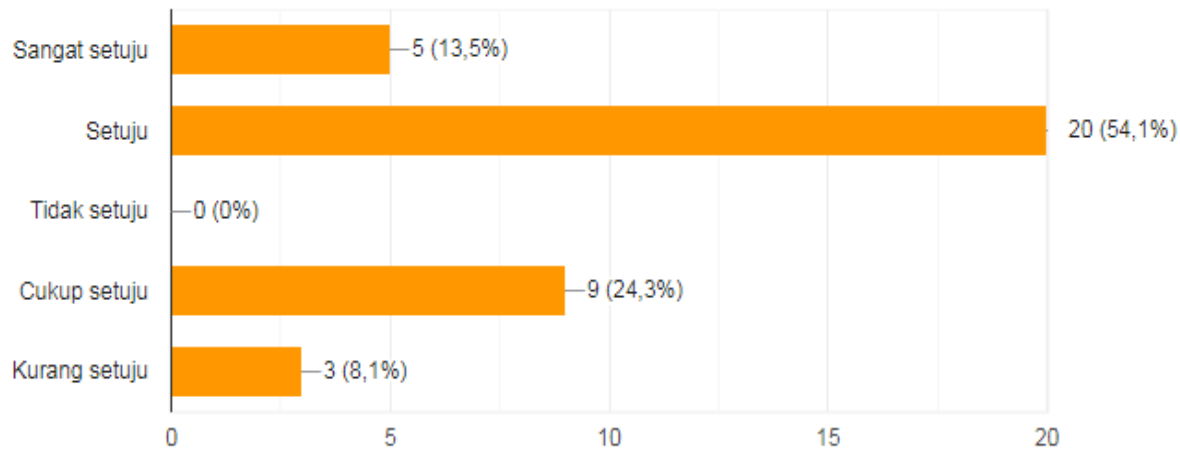

In the first questionnaire which contained a statement on the effectiveness of learning through Google Classroom, 5 students chose to strongly agree (I3.5\%), 20 students chose to agree (54.I\%), 0 students chose to disagree ( $0 \%)$, 9 students chose to quite agree $(24.3 \%)$, and 3 students chose to disagree $(8.1 \%)$ on the effectiveness of learning through Google Classroom.

Setelah terbiasa, pembelajaran melalui Google Classroom lebih efektif daripada pembelajaran dengan alat tulis kerja (manual).

37 tanggapan

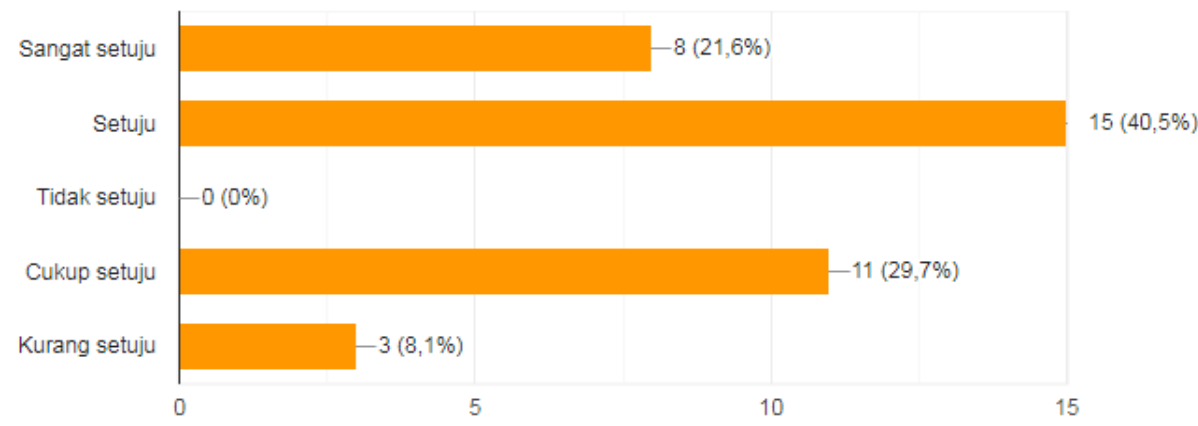

In the second questionnaire containing the statement that learning through Google Classroom was more effective than working writing tools (manual), 8 students chose to strongly agree (2I.6\%), I5 students chose to agree $(40.5 \%)$, 0 students chose to disagree (0 \%), II students chose to quite agree $(29.7 \%)$, and 3 students chose to disagree $(8.1 \%)$ on the effectiveness of learning through Google Classroom compared to writing tools (manual). 
Setelah terbiasa menggunakan Google Classroom, saya lebih semangat dalam belajar.

37 tanggapan

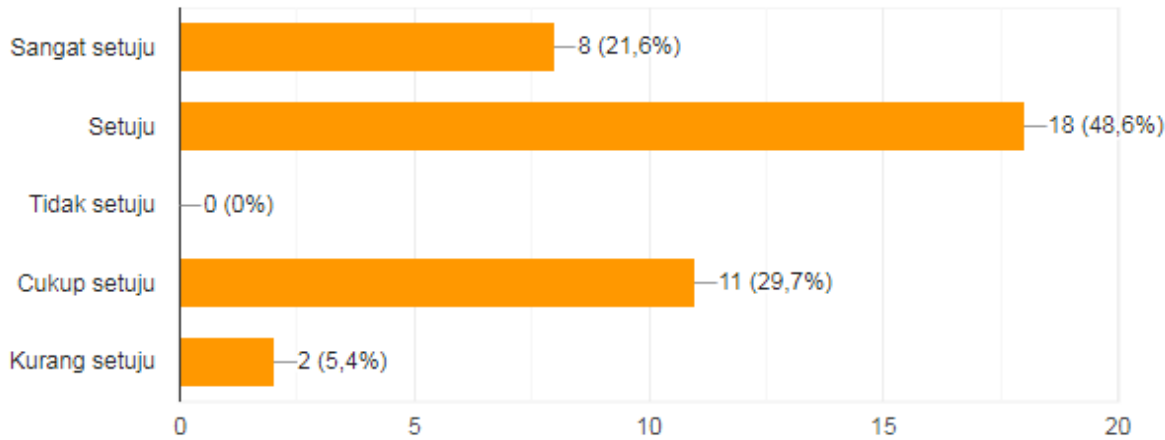

In questionnaire III, which contained a statement that students' enthusiasm for learning was better to use Google Classroom, 8 students chose to strongly agree (21.6\%), I8 students chose to agree (48.6\%), 0 students chose to disagree ( $0 \%$ ), II students choosing quite agree (29.7\%), and 2 students choosing less agree (5.4\%) on the enthusiasm of student learning for learning through Google Classroom. At the end of the lesson, students are directed to write a summary or make responses to learning according to their wishes. After carrying out product trials, the researcher evaluates the products that the researcher has developed by asking for student responses and suggestions about the implementation of Google Classroom learning and training activities so far. The results of student responses and suggestions for product evaluation are presented in tabular form, as follows:

\begin{tabular}{cl}
\hline No & $\begin{array}{c}\text { Student Responses and Suggestions on the Application of Google Classroom Assisted Active } \\
\text { Learning Model }\end{array}$ \\
\hline I & Fun learning. I like it because the material is easy to understand. \\
\hline 2 & $\begin{array}{l}\text { Hopefully in the next semester this kind of learning will be carried out again. I don't } \\
\text { get bored and feel comfortable taking notes. }\end{array}$ \\
\hline 3 & My phone network often has problems :( \\
\hline 4 & The material is very easy to understand, thank you sir. \\
\hline 5 & Practical. \\
\hline 6 & $\begin{array}{l}\text { I was nervous about answering the quiz because my answer didn't come in like other } \\
\text { friends, it turned out to be a network problem. }\end{array}$ \\
\hline 7 & My study is effective. \\
\hline 8 & $\begin{array}{l}\text { I think the Google Classroom application makes me no longer need to bother taking } \\
\text { notes because the material is already in the application. }\end{array}$ \\
\hline 9 & Hopefully other courses use this method. \\
\hline I0 & Maybe Google Classroom can be like wa, so you can know if the teacher is online. \\
\hline II & I agree with this kind of learning. \\
\hline I2 & I love this course, it's fun. \\
\hline
\end{tabular}

Table 2. Student Responses and Suggestions to the Application of Active Learning Model

Helped by Google Classroom

From the table above, it is known that students respond to active learning as an effective lecture. However, there are still obstacles to the network and facilities available to students. This response shows that active learning has helped students improve their learning outcomes.

\section{Conclusion}

Implementation of Active Learning Learning Model Using the Google Classroom Application in Comparative Literature Courses in the Indonesian Language Education Study Program, FKIP, University of Bengkulu effectively improves learning outcomes. This effectiveness can be seen from the results of product trials 
in the form of tests carried out using the google classroom application, namely the average score obtained by students participating in the training in comparison caste, which is 85.5 from a maximum average score of IOO points. Meanwhile, the lowest average score for students was on quiz 3 with a score of 60 out of 100 points, while the highest score for students in comparative literature on quiz 4 was 95 points. This shows that the implementation of the active learning model assisted by Google Classroom has resulted in a good learning process for students.

From these results it can be concluded that there is not only an increase in learning outcomes in the previous quizzes/exercises but the results of the post test also show that the learning outcomes are generally good which means the use of active learning models with google classroom assisted group discussions. In addition to good learning outcomes, the implementation of the Active Learning Learning Model using the Google Classroom Application in the Comparative Literature Course is also considered effective for students, this can be seen from the responses and suggestions from students after learning takes place.

From the results of the research that has been done, it can be concluded as follows, the use of google classroom in the Comparative Literature course in the fifth semester of class A Indonesian Language Education Study Program FKIP UNIB makes learning effective. This can be seen from the learning outcomes that are categorized as good and the results of the evaluation in the form of questionnaire results that researchers distribute to students who on average convey suggestions and responses that agree that learning activities using the active learning model assisted by google classroom are effective so that students are enthusiastic in learning activities.

Although the results obtained were good, there were obstacles that the researchers encountered during the implementation of the research. For example is the matter of network strength that is not uniform. This causes some students who are not on time during the discussion or when collecting assignments. The solution to this problem is to provide students with an understanding that an unstable network cannot be used as a persistent excuse. There needs to be an effort from students so that when learning takes place they can follow the rules and regulations such as non-online learning. Hopefully further research is expected in using google classroom lecturers to develop varied strategies so that online learning becomes more attractive to students. As well as increased student activity and learning outcomes and lecturers can also use Google Classroom in other courses.

\section{REFERENCES}

Hosnan, M. (2014). Pendekatan Saintifik dan Kontekstual dalam Pembelajaran Abad 2I. Bogor: Ghalia Indonesia. Mayasari, G. H. (20I I). Meneropong Teori Sastra Bandingan pada Buku Metodologi Penelitian Sastra Bandingan. (April), 208-2II.

Miskahuddin. (2017). Pengaruh Internet Terhadap Penurunan Minat Belajar Mahasiswa. Mudarrisuna, 7.

Putra, N. (20II). Research \& Development. Jakarta: Raja Grafindo Persada.

Suwardi. (2010). Sastra Bandingan: Metode, Teori, dan Aplikasi. Yogyakarta: FBS Universitas Negeri Yogyakarta. Widokyo. (2009). Evaluasi Program pembelajaran. Yogyakarta: Pustaka Pelajar.

Danandjaja, James. (1994). Folklor Indonesia. Jakarta: Grafiti.

Keputusan Presiden Nomor I2 Tahun 2020 tentang Penetapan Bencana Non-Alam Penyebaran CoronaVirus Disease 2019 (Covid-19) sebagai bencana nasional.

Bonwell, Charles C., dan James A. Eison. (1986). Active Learning: Creating Excitement in Boston. Boston: D. C. Health.

Nafiah dan Hartatik, S. (2020). Education and Human Development Journal. Penerapan Manajemen Pembelajaran Berbasis Daring dengan Menggunakan Aplikasi Google Classroom untuk Meningkatkan Kemampuan Mahasiswa Dalam Membuat Perangkat Pembelajaran, 5(April), 9-22. 